\title{
PENGARUH PERUBAHAN KADAR AIR TERHADAP NILAI KUAT TEKAN BEBAS STABILISASI TANAH CL-ML DENGAN SEMEN
}

\author{
Suhaimi Siregar \\ Mahasiswa Magister Teknik Sipil Universitas Riau \\ J1. HR Soebrantas KM 12,5 Pekanbaru, Kode Pos 28293 \\ Email : soehaimi.pku@gmail.com \\ Ferry Fatnanta \\ Magister Teknik Sipil Universitas Riau \\ J1. HR Soebrantas KM 12,5 Pekanbaru, Kode Pos 28293 \\ Email : fatnanto1964@gmail.com \\ Muhardi \\ Magister Teknik Sipil Universitas Riau \\ J1. HR Soebrantas KM 12,5 Pekanbaru, Kode Pos 28293 \\ Email : muhardi@eng.unri.ac.id
}

\begin{abstract}
Abstrak
Di Pekanbaru, terdapat jenis tanah yang diklasifikasikan tanah CL-ML yang berdasarkan grafik plastisitas cassagrande memiliki indek plastisitas antara $4 \%-7 \%$, dan batas cair antara $12 \%-30 \%$. Kondisi tanah ini rentan terhadap perubahan kadar air sehingga menyebabkan tanah mudah lembek (mencair) dimusim penghujan dan menjadi retak pada musim kemarau, keadaan ini menjadi masalah jika pembangunan jalan dilaksanakan diatasnya. Penelitian ini menggunakan semen sebagai stabilisasi secara kimia dalam upaya perbaikan akibat perubahan kadar air pada siklus basah-kering terhadap nilai kuat tekan bebas. Siklus pembasahan dilakukan dengan merendam sampel ke dalam air dan pengeringan dengan dimasukkan ke dalam desikator yang terjaga kelembapannya. Hasil penelitian secara umum menunjukkan bahwa karakteristik kuat tekan bebas terhadap siklus basah kering meningkat dengan penambahan semen pada tanah CL-ML. Pada kondisi pembasahan nilai kuat tekan bebas menurun dengan meningkatnya kadar air dan kembali meningkat saat kadar air berkurang pada kondisi pengeringan.
\end{abstract}

Kata Kunci : Kadar Air, Kuat Tekan Bebas, Stabilisasi Semen, Siklus Pembasahan Pengeringan, Tanah CL-ML 


\begin{abstract}
In Pekanbaru, there is type of soil classified CL-ML soil, it is according to plasticity char Casagrande has plasticity index range around $4 \%$ until 7\%, and liquid limit range around $12 \%$ until $30 \%$. This soil condition is very susceptible by changes in water content so that caused soil in wet season easier to be melted and become cracked in dry season, this situation become problem if there is road construction on it. This research used cement as a chemical stabilization in inprovement effort by considering the effect by changes in water content caused wet-dry cycle on the unconfined compressive strength value, wetting cycle done by immersing testing sample into water and drying cycle was done by put in desikator that has a constan moisture. The results of research indicated that the caracteristics of unconfined compressive strength toward wet-dry cycle increased with the addition of cement to CL-ML soil. In the wetting condition the value of compressive strength decrease with increasing moisture content and increasing again with reduced moisture content in drying condition, this is caused the calcium silicate content in the cement reacts with water to form a binder paste and harden.
\end{abstract}

Keywords : Water Content, Unconfined Compressive Strength, Cement Stabilization, Wet - Dry Cycle, CL-ML Soil

\section{A. PENDAHULUAN}

Secara geografis Kota Pekanbaru terletak pada posisi $101^{0} 14^{\prime}$ $101^{0} 34^{\prime} \mathrm{BT}$ dan $0^{0} 25^{\prime}-0^{0} 45^{\prime} \mathrm{LU}$, berada diiklim tropis yang hanya memiliki musim kemarau dan penghujan, memberikan dampak pada perubahan kadar air tanah, meningkat pada saat musim penghujan dan berkurang pada musim kering atau mengalami siklus basah-kering. Perubahan kadar air secara terus menerus akan mempengaruhi parameter tanah, yaitu sifat fisik tanah (berat volume kering tanah, kadar air, derajat kejenuhan, porositas, angka pori, specific gravity, batas atterberg), dan sifat mekanis tanah (kohesi, sudut geser dalam).

Beberapa lokasi di Kecamatan Tenayan Raya Kota Pekanbaru terdapat jenis tanah CL-ML, menurut grafik plastisitas casagrande pada gambar 1, nilai indek plastisitasnya antara $4 \%$ $7 \%$ dengan rentang batas cair $12 \%$ $30 \%$, jenis tanah ini sangat terpengaruh terhadap perubahan kadar air yang mudah menjadi lembek (mencair) dan menjadi pecah-pecah pada keadaan kering. Kondisi ini menjadi kendala apabila diatasnya dilaksanakan pekerjaan konstruksi seperti pekerjaan jalan.

Perilaku tanah CL-ML yang mudah terpengaruh pada perubahan kadar air dari siklus pembasahan dan pengeringan, sehingga dilakukan penelitian ini dengan meninjau pengaruh perubahan kadar air terhadap nilai kuat tekan bebas $\left(\mathrm{q}_{\mathrm{u}}\right)$ pada tanah CL-ML dengan menggunakan semen sebagai bahan stabilisasi.

Stabilisasi tanah merupakan upaya untuk memperbaiki mutu tanah yang tidak baik dan meningkatkan mutu tanah yang sudah tergolong baik, bertujuan untuk meningkatkan kemampuan daya dukung tanah dalam menahan beban, stabilisasi tanah dapat dilakukan secara mekanik dan kimiawi.

Pemilihan semen sebagai bahan stabilisasi karena semen dapat mengeras secara cepat dan tanpa tergantung terhadap temperatur sepanjang tidak tercapai kondisi beku dibandingkan bahan kapur yang mengalami proses 
sementasi secara bertahap pada temperatur tertentu.

Menurut Departement of The Army and The Air Force (1994) klasifikasi tanah dalam sistem Unified, penggunan semen sebagai bahan stabilisasi cocok digunakan pada tanah dengan batasan LL $<40$ dan PI $<20$.

\section{B. TINJAUAN PUSTAKA}

Tanah CL-ML pada gambar 1, grafik casagrande berada pada klasifikasi tanah berbutir (fine-graded soils) dimana lempung inorganik (inorganic clay) (C) serta lanau inorganik (inorganic silt) (M) dengan tingkat plastisitas rendah (low plasticity) (L). Indek plastisitas tanah merupakan interval kadar air dimana tanah masih bersifat plastis.

Atterberg memberi batasan indek plastisitas, sifat macam tanah, dan kohesi diberikan dalam tabel 1.

Batas cair (liquid limit) (LL) didefinisikan sebagai kadar air tanah pada batas antara keadaan cair dan keadaan plastis, yaitu batas atas dari daerah plastis.

Semen merupakan bahan perekat hidraulis, artinya akan berubah menjadi pasta pengikat ketika bereaksi dengan air karena unsur utama semen adalah kalsium dioksida, silikat dan aluminat yang bersifat hidrolis, senyawa $\mathrm{C}_{2} \mathrm{~S}$ dan $\mathrm{C}_{3} \mathrm{~S}$ menjadi unsur terpenting $(70 \%$ $80 \%$ dari semen) dalam kekuatan pengikat pasta semen.

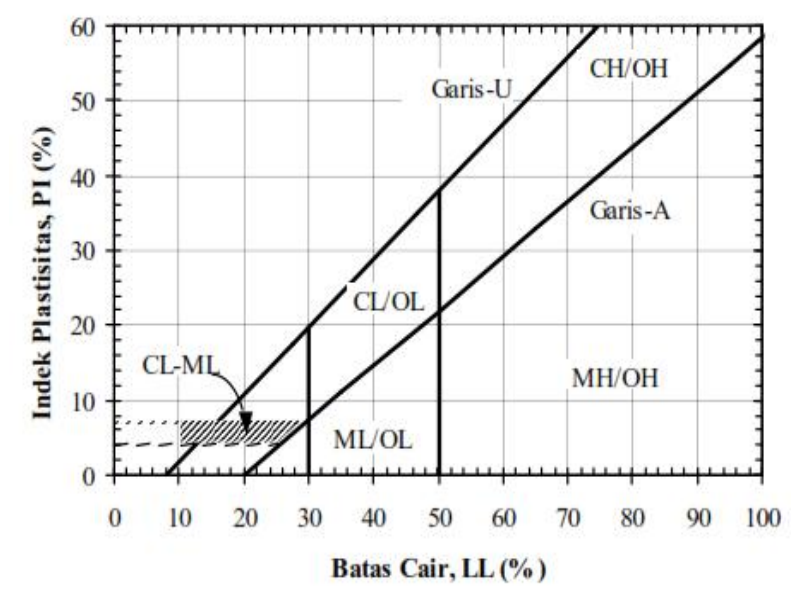

Gambar 1. Grafik Plastisitas untuk Klasifikasi Tanah USCS

Tabel 1. Nilai Indek Plastisitas dan Macam Tanah

\begin{tabular}{cccc}
\hline PI & Sifat & Macam Tanah & Kohesi \\
\hline 0 & Non Plastis & Pasir & Non kohesif \\
$<7$ & Plastisitas rendah & Lanau & Kohesif sebagian \\
$7-17$ & Plastisitas sedang & Lempung berlanau & Kohesif \\
$>17$ & Plastisitas tinggi & Lempung & Kohesif \\
\hline
\end{tabular}

(Sumber : Hardiyatmo HC., 2012)

Senyawa $\quad \mathrm{C}_{3} \mathrm{~S} \quad$ teroksidasi menghasilkan reaksi eksotermik dan berpengaruh pada panas hidrasi tinggi, kecepatan pengerasan sebelum mencapai umur 14 (empat belas) hari karena menghasilkan kalsium hidroksida hampir 3 (tiga) kali lebih banyak dari $\mathrm{C}_{2} \mathrm{~S}$, sedangkan senyawa $\mathrm{C}_{2} \mathrm{~S}$ mempunyai reaksi lebih lambat dengan air, sehingga pengaruhnya pada 
pengerasan semen setelah umur 7 (tujuh) hari (Tjokrodimuljo K., 1996).

Waktu ikatan semen merupakan waktu yang dibutuhkan oleh semen-air hingga berbentuk pasta yang secara bertahap berubah dari agak plastis hingga menjadi massa yang keras/kaku. Mindess dan Young (1981), membagi waktu ikatan menjadi 2 (dua) tahapan :

a. Waktu ikatan awal (initial setting time), yaitu waktu dari saat pertama bercampurnya semen-air sampai kehilangan sifat keplastisannya.

b. Waktu ikatan akhir (final setting time), yaitu waktu dari campuran semen air yang telah menjadi pasta berubah menjadi massa yang kaku atau keras.

Waktu ikatan sangat dipengaruhi oleh banyaknya air yang dicampurkan dan suhu, proses ikatan diikuti dengan kenaikan temperatur yang naik dengan cepat dari waktu ikatan awal sampai ikatan akhir. Pada semen waktu ikatan awal kurang dari 1 (satu) jam setelah tercampur dengan air, dan ikatan akhir kurang dari 8 (delapan) jam.

Faktor utama yang mempengaruhi kualitas campurant tanah-semen adalah :

a. Jenis tanah, tanah berbutir halus membutuhkan semen yang lebih banyak untuk menutup permukaan partikel tanah agar terjadi sementasi antar bidang kontak antara partikel lebih besar dibandingkan dengan butiran tanah lebih besar.

b. Kadar semen, untuk menentukan kadar semen yang cocok pada tanah tertentu dengan melakukan uji kuat tekan bebas pada kadar semen yang divariasikan.

c. Pemadatan, tanah dipadatkan mencapai berat volume kering (kepadatan) maksimumnya, kadar air optimum.

d. Waktu pemeraman, setelah pelaksanaan pemadatan campuran tanah-semen, dilakukan pemeraman dan perawatan sedemikian rupa sehingga pengeringan dihambat selama periode awal dari peningkatan kekuatannya secara berangsur-angsur.

e. Cara pencampuran, pelaksanaan stabilisasi tanah-semen dilapangan adalah mencampur secara merata tanah yang telah digemburkan dengan semen, pada kadar semen tertentu dan dengan kadar air yang secukupnya agar diperoleh kepadatan yang maksimum.

\section{METODE PENELITIAN}

Penelitian dilaksanakan di laboratorium dibagi dalam 2 (dua) tahapan pengujian, pengujian pertama melakukan pengujian karakteristik tanah CL-ML, tahapan kedua melakukan pengujian UCS pada tanah asli dan campuran tanah-semen dengan kadar semen $5 \%, 8 \%$ dan $12 \%$ melalui siklus pembasahan dan pengeringan. Tahapan pengujian dijelaskan dalam bagan alir gambar 2.

Sampel tanah diambil dari lokasi sekitar Jalan 70 menuju PLTU Kecamatan Tenayan Raya Kota Pekanbaru. Tanah terlebih dahulu dilakukan pengujian karakteristik tanah untuk memastikan tanah yang akan dilakukan pengujian merupakan tanah CL- ML sesuai dengan grafik plastisitas casagrande.

\section{Data Karakteristik Tanah CL- ML}

Hasil pengujian karakteristik sampel tanah diperoleh nilai Specific Gravity $=2,62$, pengujian atterberg diperoleh nilai batas cair $=27,44$, batas plastis $=21,09$, indek plastisitas $=6,35$ (tanah CL-ML), dan dari hasil pengujian standar proctor diperoleh nilai kadar air 
optimum (optimum moisture content) (OMC) sebesar 15,40\%.

Hasil pengujian analisa saringan, tanah CL-ML merupakan tanah berbutir halus sandy silty clay dengan pasir sebesar 35,52\%, lanau sebesar 46,38\%, dan lempung $18,10 \%$.

\section{Persiapan Benda Uji Campuran Tanah - Semen}

Benda uji yang disiapkan berupa tanah CL-ML, yang dihancurkan kemudian disaring dengan saringan No. 4, dikeringkan didalam oven 24 jam, tanah CL-ML kering oven dicampur semen dengan kadar semen sebesar 5\%, $8 \%$ dan $12 \%$.

Pencampuran air dilakukan dengan kadar air optimum sebesar 15,4\% dari berat tanah CL-ML kondisi kering oven, Pemadatan dengan standar proctor dalam mohl ukuran diameter 6 $\mathrm{cm}$, tinggi $15 \mathrm{~cm}$ dengan 3 (tiga) lapisan tanah atau campuran tanah-semen, pemadatan dilaksanakan dengan menggunakan standart proctor setiap lapisan dengan 10 tumbukan.

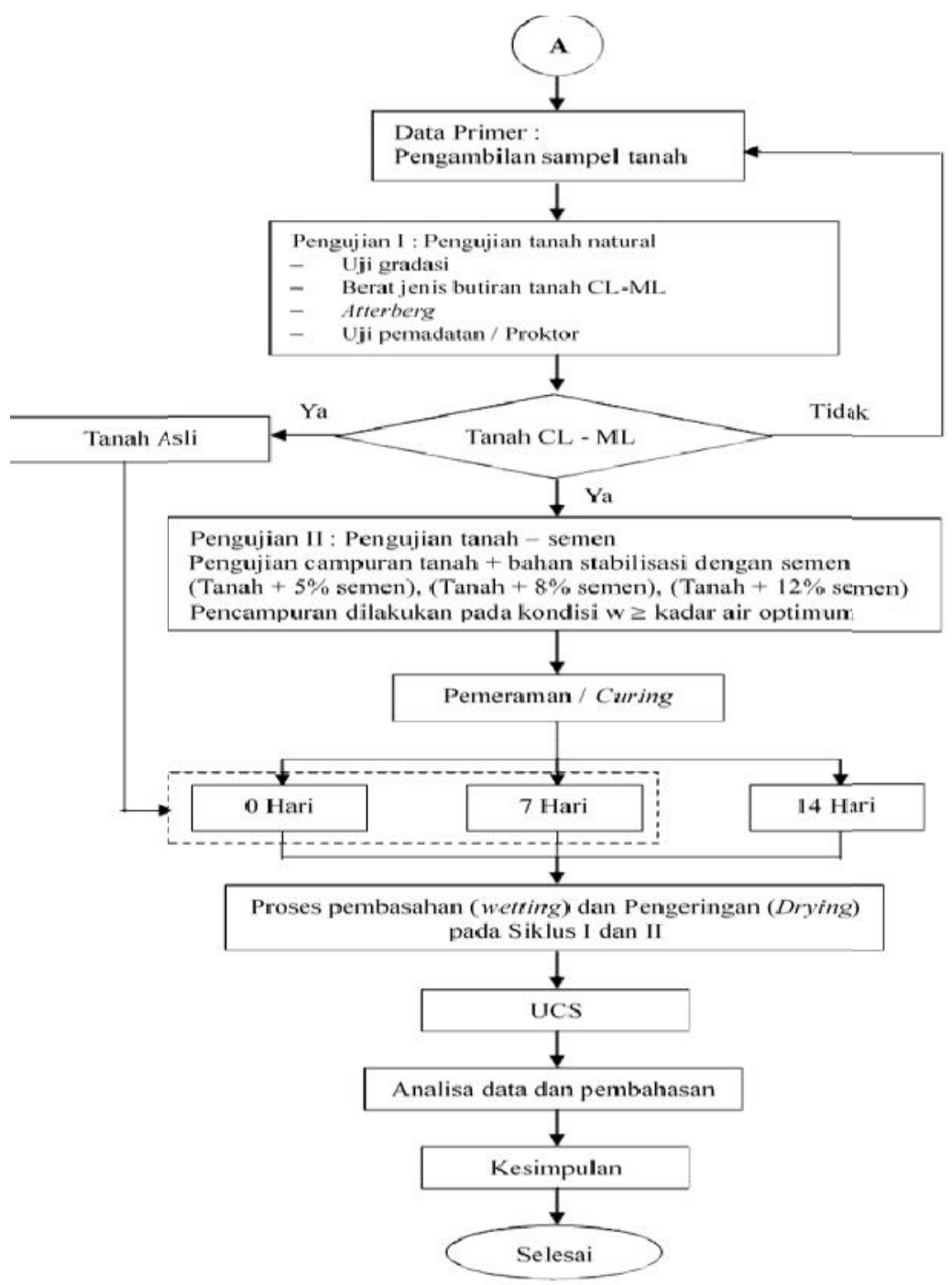

Gambar 2. Bagan Alir Pengujian 


\section{Nilai Kuat Tekan Bebas Kondisi Perendaman}

Pengujian perendaman benda uji tanah-semen dilakukan selama 3 (tiga), 5 (lima) dan 7 (tujuh) jam setelah diperam atau curing dalam desikator selama 7 (tujuh) dan 14 (empat belas) hari, diperoleh hubungan nilai kuat tekan bebas $\left(\mathrm{q}_{\mathrm{u}}\right)$ dengan campuran tanah - semen diperlihatkan pada gambar 3.

Perendaman mengakibatkan nilai kuat tekan bebas $\left(\mathrm{q}_{\mathrm{u}}\right)$ tereduksi dibandingkan dengan nilai $\mathrm{q}_{\mathrm{u}}$ benda $\mathrm{uji}$ pada kondisi setelah pemeraman.

Hasil pengujian diperoleh, untuk pemeraman 7 hari, nilai $\mathrm{q}_{\mathrm{u}}$ campuran tanah $+5 \%$ semen, OMC sebesar 1.594,79 kPa, perendaman 3 (tiga) jam sebesar 1.491,65 $\mathrm{kPa}$, perendaman 5 (lima) jam sebesar 1.415,38 kPa, perendaman 7 (tujuh) jam sebesar $1.347,91 \mathrm{kPa}$. Campuran tanah+8\% semen, OMC sebesar 1.915,36 kPa, perendaman 3 (tiga) jam sebesar 1.795,33 kPa, perendaman 5 (lima) jam sebesar 1.578,75, perendaman 7 (tujuh) jam sebesar 1.417,01 kPa. Campuran

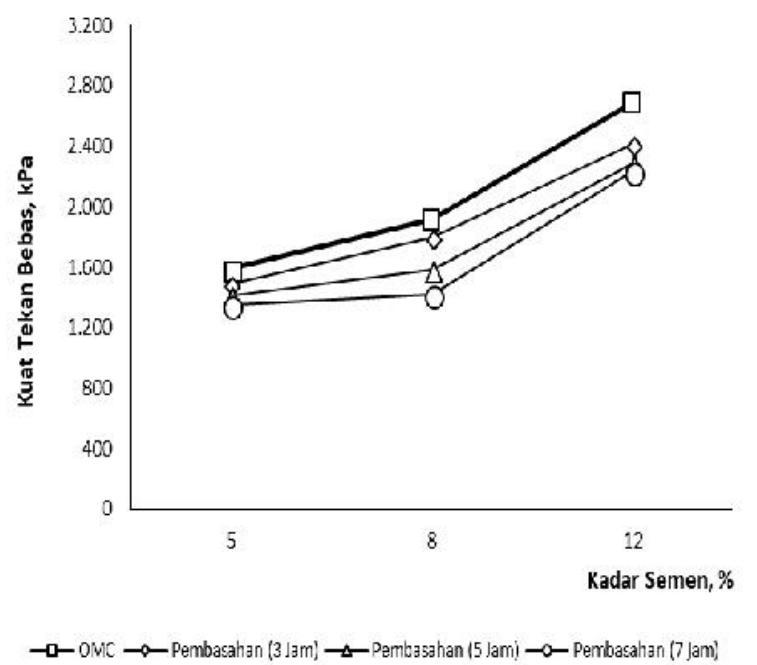

(a) tanah $+12 \%$ semen, OMC sebesar 2.691,35 kPa, perendaman 3 (tiga) jam sebesar 2.417,53 kPa, perendaman 5 (lima) jam sebesar 2.288,53 kPa, perendaman 7 (tujuh) jam sebesar 2.237,99 kPa.

Hasil pengujian nilai kuat tekan bebas pemeraman 14 hari, campuran tanah $+5 \%$ semen keadaan OMC sebesar $1.662,48 \mathrm{kPa}$, perendaman 3 (tiga) jam sebesar $1.556,17 \mathrm{kPa}$, perendaman 5 (lima) jam sebesar $1.542,70 \mathrm{kPa}$, perendaman 7 (tujuh) jam sebesar $1.495,74 \mathrm{kPa}$.

Campuran tanah $+8 \%$ semen, kondisi OMC diperoleh 2.953,22 $\mathrm{kPa}$, perendaman 3 (tiga) jam sebesar 2.815,5 $\mathrm{kPa}$, perendaman 5 (lima) jam sebesar 2.664,03 kPa, perendaman 7 (tujuh) jam sebesar 1.495,74 kPa. Campuran tanah $+12 \%$ semen, kondisi OMC diperoleh $3.670,98 \mathrm{kPa}$, perendaman 3 (tiga) jam sebesar $3.404,70 \mathrm{kPa}$, perendaman 5 (lima) jam sebesar $3.188,52 \mathrm{kPa}$, perendaman 7 (tujuh) jam sebesar $2.968,74 \mathrm{kPa}$.

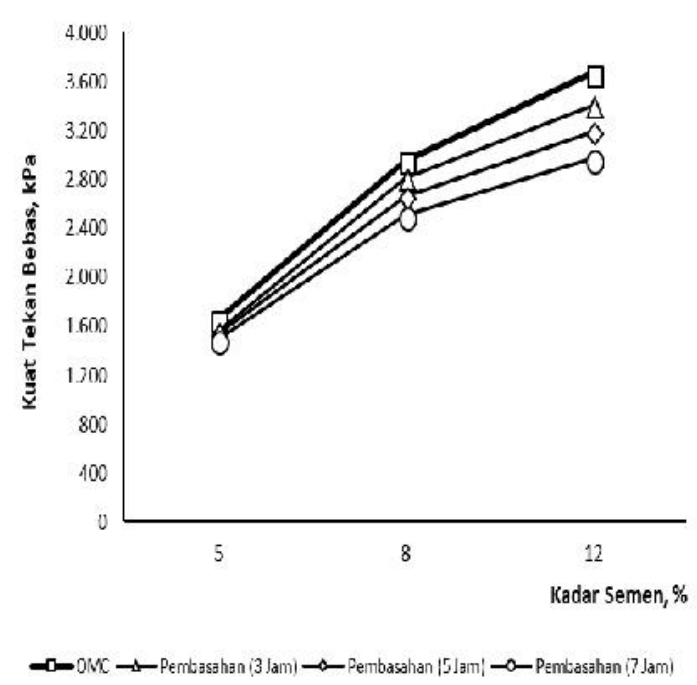

(b)

Gambar 3. Perbandingan Kuat Tekan Bebas dan Kadar Semen Kondisi OMC dan Perendaman (a) Pemeraman 7 hari (b) Pemeraman 14 hari 


\section{Nilai Kuat Tekan Bebas $\left(q_{u}\right)$}

Kadar semen yang digunakan dalam pengujian kuat tekan bebas $\left(\mathrm{q}_{\mathrm{u}}\right)$ yang mengalami siklus basah-kering divariasikan yaitu $5 \%, 8 \%$ dan $12 \%$, digambarkan dalam grafik hubungan nilai kuat tekan bebas $\left(\mathrm{q}_{\mathrm{u}}\right)$ dan waktu proses siklus basah-kering pada gambar 4. Siklus basah kering dilaksanakan sebanyak 2 siklus setelah pemeraman 0 hari, 7 hari dan 14 hari, dengan merendam benda uji selama 3 jam, 5 jam dan 7 jam dan dikeringkan selama 1 hari, 2 hari dan 3 hari dalam desikator.

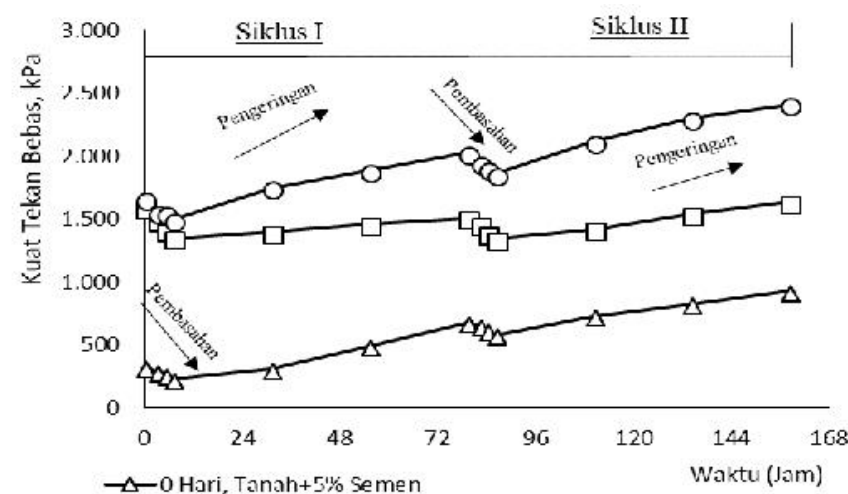

$\rightarrow-0$ Hori, Tonah+ris Semen

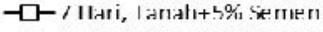

$-0-14$ hari, Tonah+5\% semen

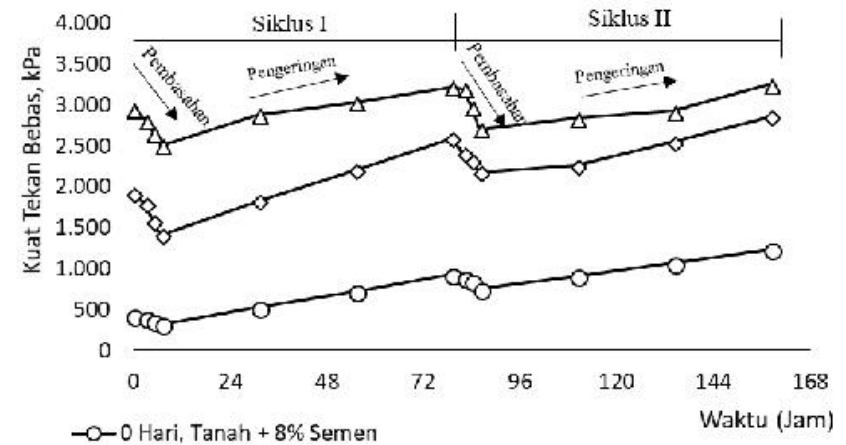

$\infty-\infty$ Hari, Tanah $+8 \%$ Semen

$\bowtie-7$ Hari, Tanah $+8 \%$ Semen

$\rightarrow-14$ Hari, Tanah $+8 \%$ Semen

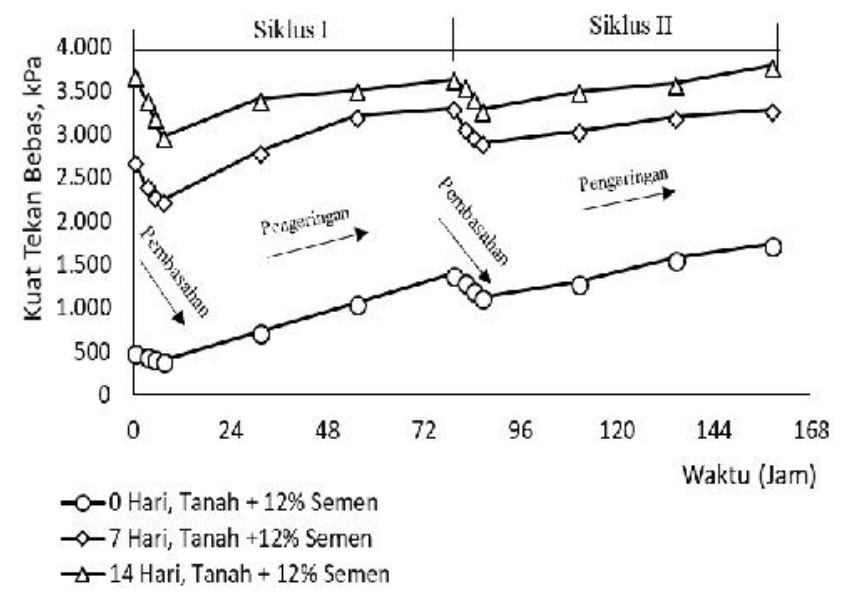

Gambar 4. Hubungan Nilai Kuat Tekan Bebas $\left(\mathrm{q}_{\mathrm{u}}\right)$ dengan Waktu Siklus Basah Kering 
Gambar 4 memperlihatkan nilai kuat tekan bebas $\left(\mathrm{q}_{\mathrm{u}}\right)$ benda uji pada siklus I (pertama) kondisi pembasahan mengalami penurunan dengan waktu perendaman 3 jam, 5 jam dan 7 jam, kemudian kembali meningkat pada proses pengeringan dengan waktu pengeringan $1 \times 24$ jam, $2 \times 24$ jam dan $3 \times 24$ jam. Siklus II (kedua) pada kondisi pembasahan dengan perendaman benda uji selama 3 jam, 5 jam dan 7 jam nilai kuat tekan bebas

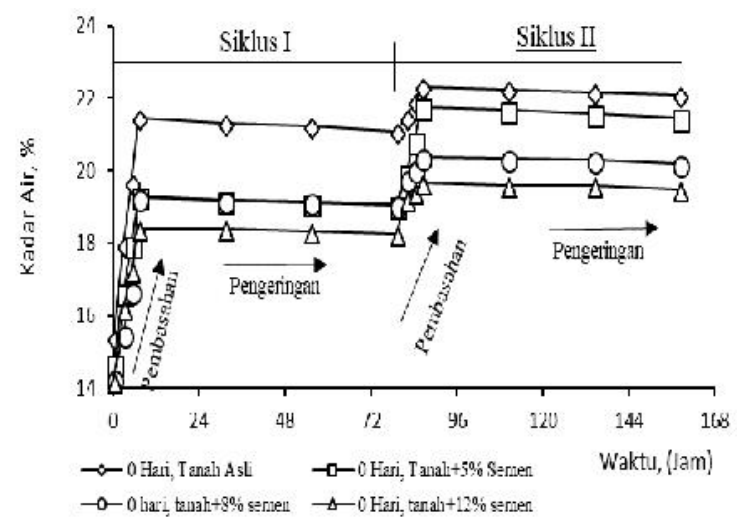

(a) $\left(\mathrm{q}_{\mathrm{u}}\right)$ kembali berkurang dan kembali meningkat pada kondisi pengeringan.

Perubahan nilai kuat tekan bebas pada siklus basah kering dipengaruhi oleh kadar air dalam benda uji melalui proses perendaman dan pengeringan. Kadar air selama pengujian pada siklus basah-kering campuran tanah-semen dengan kadar semen 5\%, 8\%, dan $12 \%$ dihubungkan dalam grafik kadar air terhadap waktu siklus basah kering selama pemeraman 0 jam dan pemeraman 7 jam diperlihatkan pada gambar 5 .

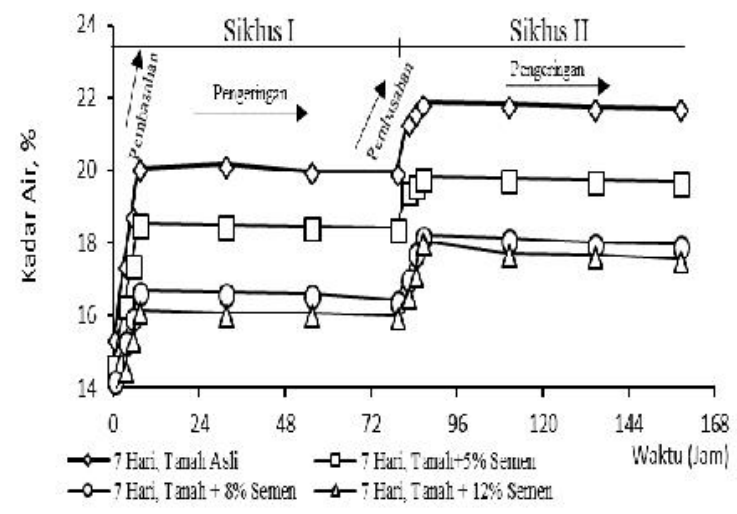

(b)

Gambar 5. Hubungan Kadar Air terhadap Waktu Siklus Basah-Kering (a) Pemeraman 0 Hari, (b) Pemeraman 7 Hari

Hasil pengujian diperoleh pada siklus I (pertama) kadar air meningkat saat perendaman benda uji (kondisi basah), dan menurun kembali pada kondisi pengeringan (kondisi kering), siklus II (kedua) kadar air kembali meningkat saat perendaman dan menurun saat kondisi kering. Kadar air juga dipengaruhi oleh kadar semen dalam campuran tanah-semen, semakin tinggi kadar semen menurunkan kadar air yang terkandung dalam benda uji.
Hasil pengujian nilai kuat tekan bebas $\left(\mathrm{q}_{\mathrm{u}}\right)$ dan kadar air selama siklus basah kering diperlihatkan pada gambar 6.

Nilai kuat tekan bebas $\left(q_{u}\right)$ dipengaruhi oleh perubahan kadar air dan kadar semen pada campuran tanahsemen, kuat tekan bebas $\left(\mathrm{q}_{\mathrm{u}}\right)$ menurun seiring bertambahnya kadar air dan meningkat dengan berkurangnya kadar air. 


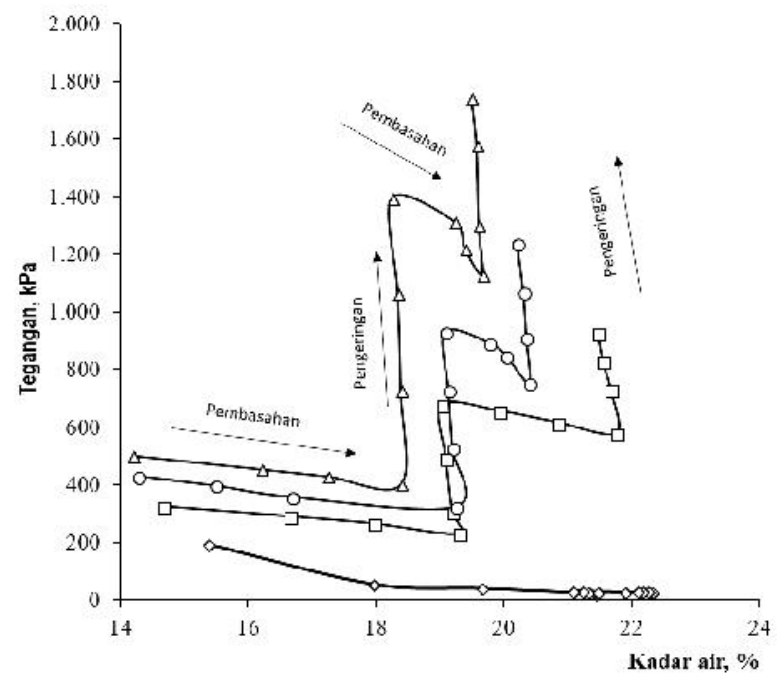

$$
\begin{array}{ll}
\rightarrow-0 \text { Hari, Tanah Asli } & -\square-\text { Tanah }+5 \% \text { Semen } \\
\rightarrow-\text { Tanah }+8 \% \text { Semen } & \rightarrow-\text { Tanah }+12 \% \text { Semen }
\end{array}
$$

(a)

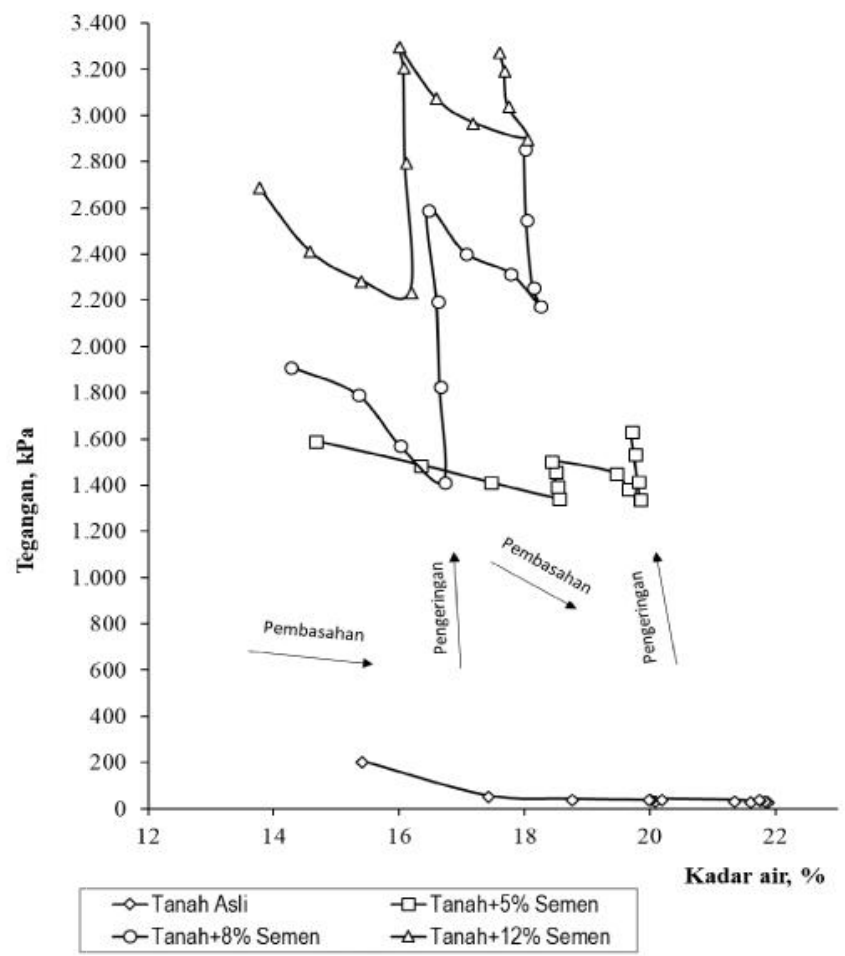

(b) 


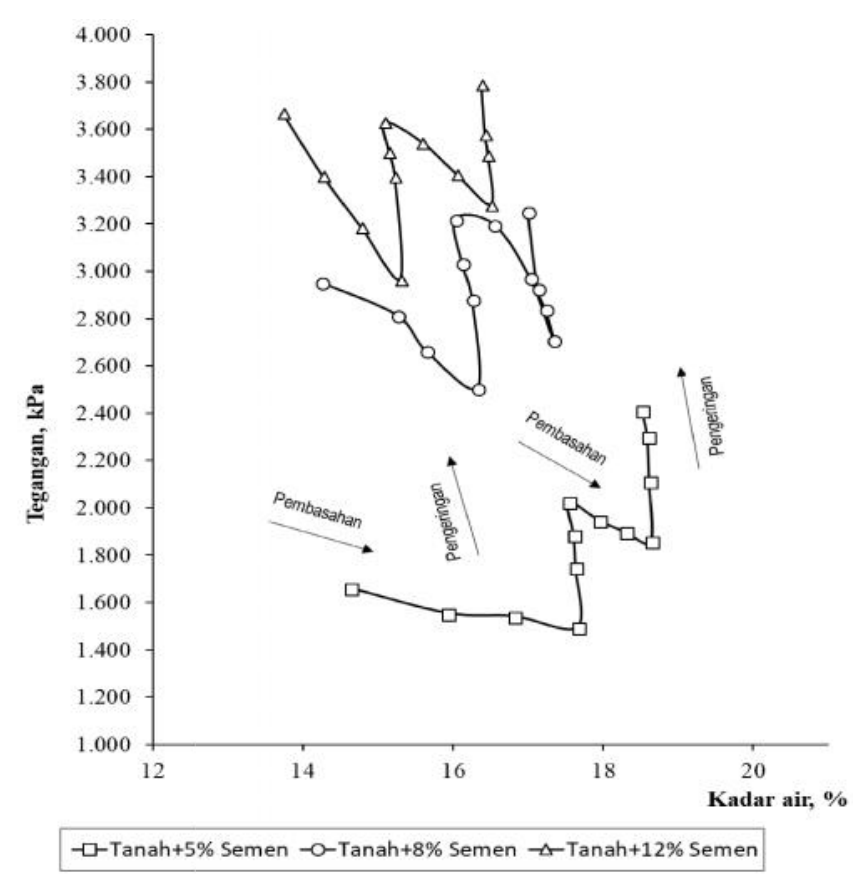

(c)

Gambar 6. Hubungan Kuat Tekan Bebas dengan Kadar Air Siklus Basah-Kering, (a) Pemeraman 0 Hari, (b) Pemeraman 7 Hari, (c) Pemeraman 14 Hari

\section{HASIL DAN PEMBAHASAN}

Perendaman mereduksi nilai kuat tekan bebas $\left(\mathrm{q}_{\mathrm{u}}\right)$ campuran tanah-semen, pemeraman 7 (tujuh) hari nilai kuat tekan bebas tereduksi sebesar 6\% $15,5 \%$ dari nilai kuat tekan bebas $\left(\mathrm{q}_{\mathrm{u}}\right)$ pada keadaan OMC setelah pemeraman 7 (tujuh) hari. Pemeraman 14 (empat belas) hari nilai kuat tekan bebas tereduksi sebesar $6 \%-10 \%$ dari nilai kuat tekan pada OMC setelah pemeraman 14 (empat belas) hari, perendaman benda uji campuran tanahsemen memperlihatkan hasil bahwa nilai kuat tekan bebas $\left(\mathrm{q}_{\mathrm{u}}\right)$ berkurang seiring dengan peningkatan kadar air pada kondisi basah (saat musim penghujan).

Nilai kuat tekan bebas $\left(q_{u}\right)$ saat direndam mengalami penurunan berbanding terbalik dengan kadar air yang terkandung dalam benda uji, pemeraman 7 (tujuh) hari kadar air campuran tanah $+5 \%$ semen meningkat $11 \%-26,5 \%$ setelah pemeraman, kadar air campuran tanah $+8 \%$ semen meningkat antara $7 \%-17,2 \%$ setelah pemeraman, sedangkan kadar air campuran tanah $+12 \%$ semen mengalami peningkatan $5 \%-17 \%$ setelah pemeraman. Peningkatan kadar air dibandingkan dengan kadar air setelah pemeraman 14 (empat belas) hari campuran tanah $+5 \%$ semen, kadar air meningkat sebesar $8 \%$ - 20,7\%, campuran tanah $+8 \%$ semen mengalami peningkatan kadar air sebesar 7\% $14,6 \%$, dan campuran tanah $+12 \%$ semen peningkatan kadar air antara $3 \%$ - 11,4\%. Kadar semen dalam campuran tanah-semen dapat berperan dalam mengurangi peningkatan kadar air yang terkandung dalam benda uji.

Kadar air pada campuran tanahsemen dengan kadar semen yang diujikan mengalami penurunan dari OMC saat pemadatan setelah disimpan dalam desikator. Pemeraman 7 (tujuh) hari untuk kadar semen 5\% kadar air berkurang 0,75 (4,9\% dari OMC), kadar 
semen $8 \%$ mengalami pengurangan kadar air sebesar 1,15 (7,5\% dari OMC) dan kadar semen $12 \%$ pengurangan kadar air sebesar $1,65 \quad(10,7 \%$ dari OMC), pemeraman 14 (empat belas) hari, untuk kadar semen 5\% pengurangan kadar airnya sebesar 0,77 (5,05\% dari OMC), kadar semen $8 \%$ pengurangan kadar air sebesar 1,16 (7,5\% dari OMC), kadar semen $12 \%$ pengurangan kadar air sebesar 1,67 $(10,9 \%$ dari $\mathrm{OMC})$, pengurangan ini disebabkan oleh reaksi semen dengan air membentuk pasta pengikat dan akibat pemeraman dalam desikator, semakin banyak kadar semen semakin banyak air yang dibutuhkan untuk reaksi membentuk pasta pengikat, dan semakin lama pemeraman semakin mengurangi kadar air karena reaksi kalsium silikat $\left(\mathrm{C}_{3} \mathrm{~S}\right.$ dan $\left.\mathrm{C}_{2} \mathrm{~S}\right)$ yang terkandung dalam semen dengan air masih berlangsung disertai dengan keluarnya air dari benda uji karena suhu saat pengeringan.

Hasil pengujian yang dilakukan dengan siklus basah-kering, menghasilkan nilai kuat tekan bebas $\left(\mathrm{q}_{\mathrm{u}}\right)$ yang bervariasi, kondisi basah sebagai idealisasi dari musim penghujan dan kondisi kering idealisasi musim kemarau, memperlihatkan nilai kuat tekan berkurang saat kondisi basah dibandingkan dengan nilai kuat tekan setelah pemeraman yang dicampur dan dipadatkan pada kadar air optimum (OMC). Nilai kuat tekan bebas kembali meningkat saat kondisi pengeringan dengan menyimpan benda uji dalam desikator dibandingkan dengan nilai kuat tekan setelah perendaman.

\section{E. KESIMPULAN}

Penambahan semen pada tanah mempengaruhi nilai kuat tekan bebas, peningkatan kadar semen berbanding lurus dengan nilai kuat tekan bebas $\left(\mathrm{q}_{\mathrm{u}}\right)$, semakin besar persentase kadar semen campuran tanah-semen nilai kuat tekan bebas $\left(\mathrm{q}_{\mathrm{u}}\right)$ semakin meningkat.

Siklus

basah-kering mempengaruhi kadar air dalam campuran tanah-semen, semakin lama waktu pembasahan maka kadar air dalam campuran tanah-semen semakin meningkat, perubahan kadar air berbeda-beda setiap campuran dipengaruhi oleh kadar semen. Peningkatan kadar air pada campuran tanah-semen mereduksi nilai kuat tekan bebas.

Nilai kuat tekan bebas $\left(\mathrm{q}_{\mathrm{u}}\right)$ kembali meningkat pada kondisi pengeringan seiring dengan berkurangnya kadar air dalam campuran tanah-semen.

\section{DAFTAR PUSTAKA}

Andriani, Rina Y., Franky L.F., 2012, Pengaruh Penggunaan Semen Sebagai Bahan Stabilisasi Pada Tanah Lempung Daerah Lambung Bukit Terhadap Nilai CBR Tanah, Jurnal Rekayasa Sipil Vol. 8.

Badan Standarisasi Nasional, 1994, Tata Cara Pembuatan Rencana Stabilisasi Tanah Dengan Semen Portland Untuk Jalan SNI 033438-1994, Jakarta, BSN.

Das BM., Mochtar NE., Mochtar IB, 1995, Mekanika Tanah (PrinsipPrinsip Rekayasa Geoteknis), Erlangga, Jakarta.

Das BM., 2006, Principles of Geotechnical Engineering, Fifth Edition, Thomson, Canada.

Hardiyanto HC., 2012, Mekanika Tanah 1, Edisi ke Enam, Gadjah Mada University Press, Yogyakarta.

Hardiyanto HC., 2010, Stabilisasi Tanah Untuk Perkerasan Jalan, Edisi Pertama, Gadjah Mada University Press, Yogyakarta. 
Harnaeni SR., 2012, Efektifitas Semen Pada Stabilisasi Lempung Dengan Kapur Akibat Percepatan Waktu Antara Pencampuran dan Pemadatan, Simposium Nasional RAPI XI FT UMS.

Pratito MJ., Safitri W., Safitri C.N., dkk, 2014, Pengaruh Siklus Pengeringan dan Pembasahan Terhadap Sifat Fisik, Mekanik dan Dinamik Pada Tanah
Tanggul Sungai Bengawan Solo Cross Section 0+500 Desa Semambung Bojonegoro Yang Distabilisasi Dengan Kapur, Fly Ash, dan Mikro Biobakteri, Jurnal Teknik POMITS Volume 1 Nomor 1.

Primadona S., Muhardi, Kurniawan A., 2015, Stabilisasi Tanah Plastisitas Rendah Dengan Semen, Jom FTEKNIK Volume 2 Nomor 2. 